\title{
Contribution of root respiration to total soil respiration during non-growing season in mine reclaimed soil with different covering-soil thicknesses
}

\author{
Min Chen ${ }^{1,2} \cdot$ Xiaoyang Chen $^{2,3} \cdot$ Zhiyong $\mathrm{Hu}^{2} \cdot$ Tingyu Fan $^{2,3} \cdot$ Shiwen Zhang ${ }^{2,3} \cdot$ \\ Ying Liu $^{2,3}$
}

Received: 11 June 2020/Revised: 27 September 2020/Accepted: 26 December 2020/Published online: 25 January 2021

(C) The Author(s) 2021

\begin{abstract}
An accurate assessment of root respiration in mine reclaimed soil is important for effectively evaluating mining area ecosystems. This study investigated dynamic changes in root respiration and the contribution of root respiration to total soil respiration $\left(R_{\mathrm{r}} / R_{\mathrm{t}}\right.$ ratio) during the non-growing season in mine reclaimed soil, with different covering-soil thicknesses. According to the covering-soil thicknesses, the study area was divided into four sites: 10-25 cm (site A), 25-45 cm (site B), 45-55 cm (site C), and 55-65 cm (site D). From November 2017 to April 2018 (except February in 2018), the soil respiration, root respiration, temperature at $5 \mathrm{~cm}$, water content, and root biomass were measured. The results show that soil temperature and root respiration exhibited similar diurnal and monthly variations. The root respiration is strongly influenced by soil temperature during the non-growing season, with an exponential and positive relationship $(P<0.001)$. Root respiration varies with the covering-soil thickness and is greatest with a covering-soil thickness of $25-45 \mathrm{~cm}$. The $R_{\mathrm{r}} / R_{\mathrm{t}}$ ratio also exhibits monthly variations. During the non-growing season, the mean value of the $R_{\mathrm{r}} / R_{\mathrm{t}}$ ratio is $51.15 \%$ in mine reclaimed soil. The study indicates that root respiration is the primary source of soil respiration and is an important factor for estimating the potential emission of soil $\mathrm{CO}_{2}$ from mine reclaimed soil at the regional scale.
\end{abstract}

Keywords Root respiration $\cdot$ Soil respiration $\cdot$ Soil temperature $\cdot$ Soil water content $\cdot$ Root biomass

Supplementary Information The online version contains supplementary material available at https://doi.org/10.1007/s40789020-00402-4.

Xiaoyang Chen

chenxy@aust.edu.cn

$1 \quad$ State Key Laboratory of Mining Response and Disaster Prevention and Control in Deep Coal Mines (Anhui University of Science and Technology), Huainan 232001, Anhui, China

2 School of Earth and Environment, Anhui University of Science and Technology, Huainan 232001, Anhui, China

3 Anhui Engineering Laboratory for Comprehensive Utilization of Water and Soil Resources \& Ecological Protection in Mining Area with High Groundwater Level, Huainan 232001, Anhui, China

\section{Introduction}

Coal mining has made a substantial contribution to the development of the international economy, but coal mining can lead to complex ground deformation processes, resulting in environmental problems and serious geological disasters (Hu et al. 2018; Sokolov et al. 2015; Wang et al. 2017b). To improve the soil ecology in coal mining areas, land reclamation technology is often utilized (Chugh 2018; Cheng et al. 2019). Backfilling with coal gangue is an economical and effective way to reclaim a damaged soil for restoring and improving the ecological environment. It can rehabilitate subsiding land and partly resolve the problem of excess coal gangue piled up on the land surface (Hu et al. 2009; Xiao et al. 2014).

However, the hydraulic properties of coal gangue are significantly different from those of soil. Zhou et al. (2010) found that the soil infiltration rate and saturated hydraulic conductivity decreased with increasing gangue content. 
Chen et al. (2018a) indicated that there was a lower waterholding capacity, and higher water and air permeability in coal gangue compared with soil. In addition, the presence of coal gangue can have a significant impact on the soil temperature and water content in mine reclaimed soil. The temperature amplitude of topsoil has been found to decrease with an increase in the covering-soil thicknesses (Chen et al. 2017) and the surface volumetric water content of a soil column filled with coal gangue has been reported to be significantly lower than that of a column solely consisting of soil (Wang et al. 2017a). Soil temperature and water content have been identified as the most important environmental factors that influence soil respiration and root respiration (Fu et al. 2019; Thurgood et al. 2014; Bi et al. 2019). The soil respiration of reclaimed soil is therefore different from that of forest, grassland, and agricultural ecosystems.

Soil root respiration constitutes an important part of overall soil respiration, and is important for evaluating the effects of ecological restoration, and calculating the turnover rates of soil organic matter pools and the carbon budgets of vegetation (Lee et al. 2003; Li et al. $2011,2010,2016)$. The contribution of root respiration to total soil respiration $\left(R_{\mathrm{r}} / R_{\mathrm{t}}\right.$ ratio $)$ is therefore important for understanding the mechanism of soil respiration and the carbon cycle (Dyukarev 2017). However, previous studies have paid relatively little attention to the $R_{\mathrm{r}} / R_{\mathrm{t}}$ ratio during the non-growing season. Although the soil temperature, microbial activity, and root biomass during the nongrowing season are obviously lower than growing season (Hao and Jiang 2014; Li et al. 2018), and even the microbial activity is negligible in frozen soils (Wang et al. 2009), the contribution of soil respiration to the total annual soil respiration has been reported to be approximately $12 \%$ and the $R_{\mathrm{r}} / R_{\mathrm{t}}$ ratio varies from $13 \%$ to $50 \%$ (Schindlbacher et al. 2007). Root respiration during the non-growing season is therefore a significant component of the annual carbon budget. Most studies of root respiration have concentrated on ecological systems, such as forest, grassland, and farmland. Zeng et al. (2016) found that annual mean $R_{\mathrm{r}} / R_{\mathrm{t}}$ ratios were $17.46 \%$ and $24.44 \%$ in $A r$ meniaca sibirica Lam. and Vitex negundo Linn. var. heterophylla forests in a semi-arid region of north China. Li et al. (2018) reported average $R_{\mathrm{r}} / R_{\mathrm{t}}$ ratios of $41.7 \%$ and $41.9 \%$ for the growing season in 2008 and 2009 in the semi-arid grassland of northern China. Hao and Jiang (2014) found that the $R_{\mathrm{r}} / R_{\mathrm{t}}$ ratio averaged $44.2 \%$ in a rape (Brassica campestris L.) field in southwest China. However, the $R_{\mathrm{r}} / R_{\mathrm{t}}$ ratio in mine reclaimed ecological systems has rarely been reported (Jørgensen et al. 2012).

Therefore, this study investigated the dynamic changes of root respiration and analyzed the $R_{\mathrm{r}} / R_{\mathrm{t}}$ ratio in mine reclaimed soil during the non-growing season. The specific aims were to: (1) obtain the dynamic changes of root respiration in mine reclaimed soil; (2) analyze the soil temperature and water content sensitivity of root respiration in mine reclaimed soil; and (3) investigate the $R_{\mathrm{r}} / R_{\mathrm{t}}$ ratio in mine reclaimed soil.

\section{Materials and methods}

\subsection{Site description}

The experiment was conducted in the ecological restoration area of Panyi Coal Mine, Huainan City, Anhui Province $\left(\mathrm{E} 116.83^{\circ}, \mathrm{N} 32.78^{\circ}\right)$. The site has a total subsided area of about 10.8 ha, but the size of the actual study area was about 5.4 ha. The study area experiences a warm temperate semi-humid continental monsoon climate, with an annual mean temperature of $15.3^{\circ} \mathrm{C}$ and average annual precipitation of $937 \mathrm{~mm}$. There is a total of $2279.2 \mathrm{~h}$ of sunshine per year and an average of $141 \mathrm{~d}$ of frost. Relative humidity in the area is $76 \%$. The ecological restoration area is part of a national mine geological environment control project, which aims to restore areas affected by coal mining subsidence. The ecological restoration area has been restored by the backfilling of coal gangue ten years ago. The vegetation is uniformly distributed and mainly consists of trees, shrubs, and weeds (Fig. S1). The topsoil is a loam clay, with a $\mathrm{pH}$ value of 7.76-8.02 and a density of $1.74-1.97 \mathrm{~g} / \mathrm{cm}^{3}$. The soil structure and texture were similar, but the covering-soil thickness varied throughout the area.

\subsection{Experimental design}

An extensive investigation revealed that the covering-soil thickness was mainly between 10 and $70 \mathrm{~cm}$ in the study area. On the basis of the overall characterization of differences in the covering-soil thickness and vegetation type, four sites were chosen as a study area within the ecological restoration area (Table 1). The covering-soil thicknesses were 10-25 cm (site A), 25-45 cm (site B), 45-55 cm (site C), and 55-65 cm (site D), respectively. A trenching

Table 1 The covering-soil thickness of the experimental areas

\begin{tabular}{llll}
\hline Site & $\begin{array}{l}\text { Sampling } \\
\text { area }(\mathrm{m} \times \mathrm{m})\end{array}$ & $\begin{array}{l}\text { Depth detection } \\
\text { point number }\end{array}$ & $\begin{array}{l}\text { The range of covering } \\
\text { soil thickness }(\mathrm{cm})\end{array}$ \\
\hline A & $20 \times 20$ & 22 & $10-25$ \\
B & $20 \times 20$ & 23 & $25-45$ \\
C & $20 \times 20$ & 22 & $45-55$ \\
D & $20 \times 20$ & 23 & $55-60$ \\
\hline
\end{tabular}


method was used to measure root respiration (Hao and Jiang 2014). Four trench plots with an area of $0.4 \mathrm{~m} \times 0.4 \mathrm{~m}$ and depth of $0.4 \mathrm{~m}$ were randomly established as root-free plots, and four other plots $(0.4 \mathrm{~m} \times 0.4 \mathrm{~m})$ were established as control plots in each experimental site $(20 \mathrm{~m} \times 20 \mathrm{~m})$. All plant roots in trenches were cut and carefully removed. Polyethylene sheets were then placed around the trenches to prevent the inward growth of the surrounding plant roots. Finally, the soil was refilled to match the original soil profile (Fig. S2). The root-free plots were kept free of vegetation by periodic manual removal. Monitoring began after three months. The soil temperature, water content, root biomass, soil respiration, and root respiration were continuously monitored in the plots for $4 \mathrm{~d}$ in the middle of every month from November 2017 to April 2018. Monitoring occurred every $2 \mathrm{~h}$ between 8 a.m. and 6 p.m..

\subsection{Soil respiration}

Soil respiration was measured using a closed chamber system, with a pump suction infrared gas $\mathrm{CO}_{2}$ analyzer (Mu et al. 2008). Polyvinyl chloride (PVC) barrels $(11 \mathrm{~cm}$ inner diameter, $25 \mathrm{~cm}$ height) were used to close the chamber. Before measurements, plants in the topsoil were removed with scissors to minimize the effects of plant respiration. The PVC barrels were inserted $10 \mathrm{~cm}$ into the soil to prevent gas leakage from the bottom of the barrels. The background $\mathrm{CO}_{2}$ concentrations in the PVC barrels were recorded before measurement. A pump suction infrared gas analyzer was then inserted into the PVC barrels to measure the $\mathrm{CO}_{2}$ concentration. The soil respiration was calculated by the following equation (Tomotsune et al. 2013):

$F\left(\mathrm{CO}_{2}\right)=\frac{\rho \times \Delta C \times V}{S \times \Delta t} \times \frac{273+T}{273}$

where, $\rho$ is the $\mathrm{CO}_{2}$ density in the standard state, $\Delta C$ is the change in the $\mathrm{CO}_{2}$ volume fraction, $\Delta t$ is the timing of specimen collection, $S$ is the bottom surface area of a PVC barrel, $V$ is the volume of a PVC barrel, and $T$ is the soil temperature.

\subsection{Root respiration and environmental factors}

In the trenching method, the root respiration rate was calculated using the following equation (Li et al. 2018):

$R_{\mathrm{r}}=R_{\mathrm{t}}-R_{\mathrm{m}}$

where, $R_{\mathrm{r}}$ is root respiration, and $R_{\mathrm{t}}$ and $R_{\mathrm{m}}$ are total soil respiration and microbial respiration, which were measured in the control plots and the root-free plots, respectively.
In addition, the soil temperatures were measured simultaneously with a soil temperature probe, the soil water content was measured with a portable moisture probe meter at $5 \mathrm{~cm}$ depth and soil microbial biomass was determined by a chloroform fumigation-extraction method (Zhang et al. 2016).

\subsection{Data analysis}

A non-linear regression analysis was applied to examine the relationship between root respiration and soil temperature/water content. Because scatterplots revealed a nonlinear behavior for some of the above variables, a step-wise multiple regression analysis was performed to determine the best fit linear model for the independent variables. All the statistical analyses were tested at a significance level of 0.05 with SPSS 22.0 and all figures were created using OriginPro 9.0 (Origin Lab, Northampton, MA, USA).

\section{Results}

\subsection{Diurnal variation of topsoil temperature and root respiration}

There were obvious variations in the soil temperature at all sites at a depth of $5 \mathrm{~cm}$ during the non-growing season (Fig. 1). In general, the temperature rose substantially and then reduced slowly, with the results plotted as a curve with a single-peak. The range of soil temperature changes followed the order of April (2018) $>$ March (2018) $>$ November $\quad$ (2017) $>$ December $\quad$ (2017) $>$ January (2018). The peak topsoil temperature generally occurred between 12:00 and 14:00 from November 2017 to January 2018, but it occurred between 14:00 and 16:00 in March and April 2018. However, the range of soil temperature changes was different for different covering-soil

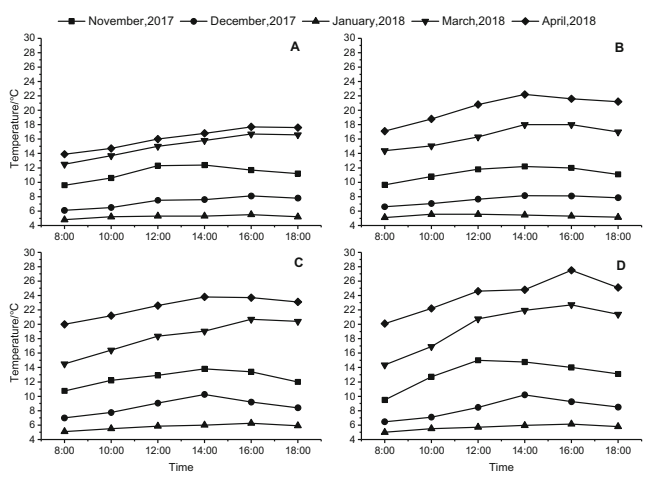

Fig. 1 Diurnal variation of the topsoil temperature at $5 \mathrm{~cm}$ at study sites with different covering-soil thicknesses form November 2017 to April 2018 (the covering-soil thicknesses of site A, B, C and D were $10-25,25-45,45-55$ and $55-65 \mathrm{~cm}$, respectively) 
thicknesses, with a general tendency to increase as the covering-soil thickness increased. The diurnal variations of root respiration were also plotted as a curve with a single peak (Fig. 2). The peak root respiration mainly occurred at 12 p.m.-16 p.m. during the non-growing season. At all sites, the diurnal variations of root respiration were smallest in January 2018, with almost no fluctuation, whereas there were obvious fluctuations in November 2017 and April 2018. Moreover, the daily changes in the range of root respiration varied with covering-soil thickness and followed the order of sites B $>$ D $>$ A $>$ C in each month.

\subsection{Monthly variation of controlling factors and root respiration}

The monthly variation trends of the soil temperature were consistent at the four sites, with a slow decrease from November 2017 to January 2018 and then a rapid increase from January 2018 to April 2018 (Fig. 3). The monthly variations of the soil temperature varied with the coveringsoil thickness. The average soil temperatures of sites A, B, $\mathrm{C}$, and D were $12.16,12.18,13.45$, and $14.18{ }^{\circ} \mathrm{C}$, respectively. The differences in soil temperature between the four sites were small when the temperature was low, but the differences gradually increased as the temperature increased. For example, in January 2018, the range of soil temperatures between the four sites was $5.2-5.7^{\circ} \mathrm{C}$, whereas it was $21.1-24.1^{\circ} \mathrm{C}$ in April 2018. The monthly variations of soil water content were the opposite of those observed for soil temperature (Fig. 3). The soil water content increased from November 2017 to January 2018 and then reduced rapidly from January 2018 to April 2018. The average water content of sites $\mathrm{A}, \mathrm{B}, \mathrm{C}$, and D were $22.44 \%, 23.66 \%, 24.13 \%$ and $23.76 \%$, respectively. In addition, there was a pronounced monthly variation in root respiration (Fig. 4), which decreased from November 2017 to January 2018 and then increased from January 2018 to

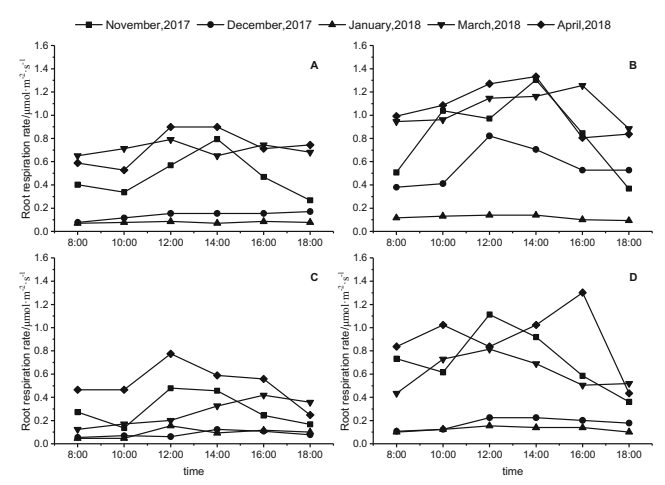

Fig. 2 Diurnal variation in root respiration at study sites with different covering-soil thicknesses form November 2017 to April 2018 (the covering-soil thicknesses of site A, B, C and D were 10-25, $25-45,45-55$ and $55-65 \mathrm{~cm}$, respectively)

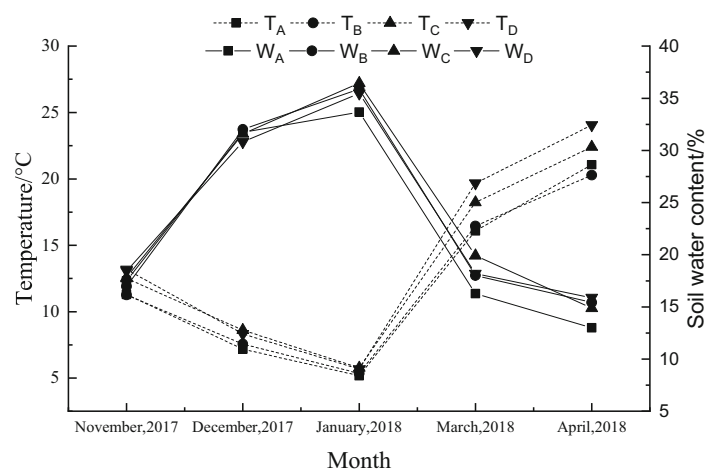

Fig. 3 Monthly variations of the soil temperature $\left(T_{\mathrm{A}}, T_{\mathrm{B}}, T_{\mathrm{C}}, T_{\mathrm{D}}\right)$ and soil water content $\left(W_{\mathrm{A}}, W_{\mathrm{B}}, W_{\mathrm{C}}, W_{\mathrm{D}}\right)$ at study sites with different covering-soil thicknesses form November 2017 to April 2018 (the covering-soil thicknesses of site A, B, C and D were 10-25, 25-45, $45-55$ and $55-65 \mathrm{~cm}$, respectively)

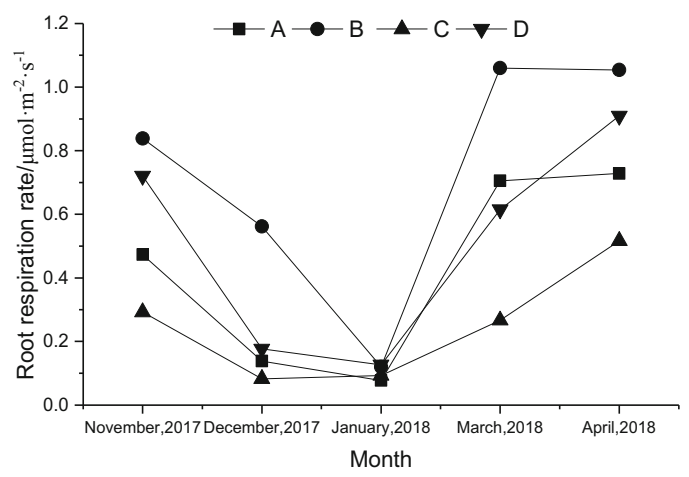

Fig. 4 Monthly variation of the root respiration at study sites with different covering-soil thicknesses form November 2017 to April 2018 (the covering-soil thicknesses of site A, B, C and D were 10-25, $25-45,45-55$ and $55-65 \mathrm{~cm}$, respectively)

April 2018. The maximum root respiration occurred in April 2018 and the minimum occurred in January 2018. The monthly variation trends of root respiration were similar to those of soil temperature. Root respiration was obviously affected by the covering-soil thickness. The range of root respiration at the four sites followed the order of $\mathrm{B}>\mathrm{D}>\mathrm{A}>\mathrm{C}$ and the average values were 0.727 , $0.510,0.425$, and $0.245 \mu \mathrm{mol} /\left(\mathrm{m}^{2} \mathrm{~s}\right)$, respectively, during the non-growing season.

\subsection{Relationships of soil temperature and water content with root respiration}

The root respiration and soil temperature were evaluated by a regression analysis at all sites (Fig. 5). During the nongrowing season, root respiration had an exponential and positive relationship with soil temperature, with $R^{2}=0.87$ $(P<0.01), R^{2}=0.66(P<0.01), R^{2}=0.61(P<0.01)$, and $R^{2}=0.84(P<0.01)$ at sites $\mathrm{A}, \mathrm{B}, \mathrm{C}$, and $\mathrm{D}$, respectively. In addition, the measurement points were plotted 


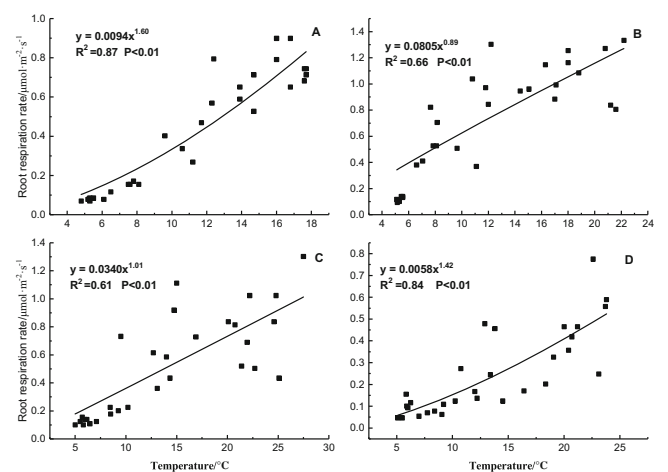

Fig. 5 Relationship between root respiration and soil temperature at $5 \mathrm{~cm}$ at study sites with different covering-soil thicknesses (the covering-soil thicknesses of site A, B, C and D were 10-25, 25-45, $45-55$ and $55-65 \mathrm{~cm}$, respectively)

closely together above and below the fitting curve, but as the temperature increased the measurement points become more dispersed. The results showed that the sensitivity of root respiration to soil temperature increased as the topsoil temperature increased. However, there was no significant correlation $(P>0.05)$ between root respiration and soil water content (Fig. 6).

\subsection{Contribution of root respiration to total soil respiration}

The monthly variations of the $R_{\mathrm{r}} / R_{\mathrm{t}}$ ratio were irregular and differed among sites A, B, C, and D (Table 2). The lowest values of the $R_{\mathrm{r}} / R_{\mathrm{t}}$ ratio occurred in December 2017, January 2018, March 2018, and December 2017, and the highest values occurred in March 2018, December 2017, December 2017, and April 2018 at sites A, B, C, and D, respectively. During the non-growing season, the $R_{\mathrm{r}} / R_{\mathrm{t}}$ ratios of sites A, B C, and D were $16.16 \%-62.05 \%$, $54.07 \%-83.02 \%, 28.26 \%-53.48 \%$, and $48.41 \%-67.18 \%$, respectively, with mean values of $43.59 \%, 61.94 \%$,
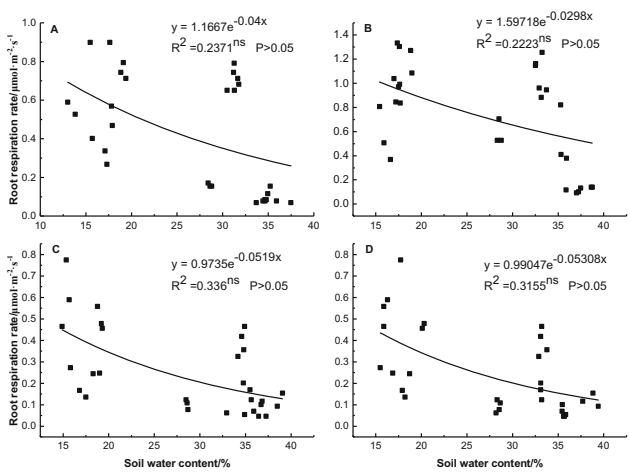

Fig. 6 Relationship between root respiration and soil water content at study sites with different covering-soil thicknesses (the covering-soil thicknesses of site A, B, C and D were 10-25, 25-45, 45-55 and $55-65 \mathrm{~cm}$, respectively)
$42.88 \%$, and $56.54 \%$, respectively. The range of $R_{\mathrm{r}} / R_{\mathrm{t}}$ ratios from high to low was $\mathrm{B}>\mathrm{D}>\mathrm{A}>\mathrm{C}$ and the highest mean value of the $R_{\mathrm{r}} / R_{\mathrm{t}}$ ratio (site $\mathrm{B}$ ) was $19.06 \%$ higher than the lowest $R_{\mathrm{r}} / R_{\mathrm{t}}$ ratio (site $\mathrm{C}$ ). The results showed that the $R_{\mathrm{r}} / R_{\mathrm{t}}$ ratio was affected by the coveringsoil thickness. However, the $R_{\mathrm{r}} / R_{\mathrm{t}}$ ratio of the entire study area displayed a pronounced monthly variation (Fig. 7), with a decrease from November 2017 to December 2017 and then a significant increase from December 2017 to April 2018. During the non-growing season the range of the $R_{\mathrm{r}} / R_{\mathrm{t}}$ ratio was $46.42 \%-57.20 \%$, with a mean value of $51.15 \%$.

\section{Discussion}

\subsection{Effects of covering-soil thickness and the factors controlling root respiration}

The artificial soil of the study area was obviously different from a natural soil (Zhang et al. 2007). The coal gangue layer changes the hydraulic properties and organic carbon content in a reclaimed soil (Chen et al. 2018a, b). Previous studies found that the water content, microbial biomass carbon (MBC), and dissolved organic carbon (DOC) content are lower with a thin covering-soil (Chen et al. 2016), which would limit root growth. The negative effects of coal gangue on root growth is weakened as the covering-soil thickness increases, but if the covering-soil is too thick it will not be conducive to MBC and DOC accumulation in surface soil (Chen et al. 2016). In our study, there were significant differences in root biomass at the four sites. The root biomass of sites A, B, C, and D were 90, 186.2, 48.3, and $149.3 \mathrm{~g} / \mathrm{m}^{2}$, respectively, and the root biomass of site B was significantly higher than that of site D (Fig. 8), which was consistent with the results of the studies referred to above. Strangely, the root biomass was smallest at site $\mathrm{C}$, whereas it was expected that it should be greater than at site A. This may be because the artificial disturbance reduced plant metabolism and even led to the death of surface grasses. Root respiration was positively correlated with soil temperature at $5 \mathrm{~cm}(P<0.01)$, but not with soil water content $(P>0.05)$. Therefore, soil temperature was the one of the main factors controlling root respiration during the non-growing season. However, the soil water content did not have significant effects on root respiration in our study, which was consistent with the results of Yan et al. (2010). Previous studies found that root respiration had a significant positive correlation with root bio-mass and topsoil temperature (Lai et al. 2017; Li et al. 2013). Due to the root biomass and topsoil temperature being affected by covering-soil thickness in mine reclaimed soil 
Table 2 The contribution of root respiration to total soil respiration with different covering-soil thicknesses

\begin{tabular}{|c|c|c|c|c|}
\hline Site & Month & $\begin{array}{l}\text { Root respiration } \\
\left(\mu \mathrm{mol} /\left(\mathrm{m}^{2} \mathrm{~s}\right)\right)\end{array}$ & $\begin{array}{l}\text { Soil respiration } \\
\left(\mu \mathrm{mol} /\left(\mathrm{m}^{2} \mathrm{~s}\right)\right)\end{array}$ & $\begin{array}{l}\text { Contribution } \\
\text { rate }(\%)\end{array}$ \\
\hline \multirow[t]{6}{*}{ A } & November, 2017 & 0.473 & 1.228 & 38.54 \\
\hline & December, 2017 & 0.138 & 0.855 & 16.16 \\
\hline & January, 2018 & 0.078 & 0.189 & 41.10 \\
\hline & March, 2018 & 0.705 & 1.137 & 62.05 \\
\hline & April, 2018 & 0.729 & 1.462 & 49.82 \\
\hline & Average & 0.425 & 0.974 & 43.59 \\
\hline \multirow[t]{6}{*}{ B } & November, 2017 & 0.839 & 1.337 & 62.72 \\
\hline & December, 2017 & 0.562 & 0.677 & 83.02 \\
\hline & January, 2018 & 0.120 & 0.222 & 54.07 \\
\hline & March, 2018 & 1.060 & 1.808 & 58.62 \\
\hline & April, 2018 & 1.054 & 1.824 & 57.79 \\
\hline & Average & 0.727 & 1.174 & 61.94 \\
\hline \multirow[t]{6}{*}{$\mathrm{C}$} & November, 2017 & 0.293 & 0.635 & 46.07 \\
\hline & December, 2017 & 0.083 & 0.172 & 48.12 \\
\hline & January, 2018 & 0.093 & 0.203 & 45.86 \\
\hline & March, 2018 & 0.267 & 0.943 & 28.26 \\
\hline & April, 2018 & 0.517 & 0.966 & 53.48 \\
\hline & Average & 0.245 & 0.584 & 42.88 \\
\hline \multirow[t]{6}{*}{$\mathrm{D}$} & November, 2017 & 0.721 & 1.399 & 51.53 \\
\hline & December, 2017 & 0.177 & 0.366 & 48.41 \\
\hline & January, 2018 & 0.127 & 0.239 & 52.97 \\
\hline & March, 2018 & 0.615 & 1.151 & 53.42 \\
\hline & April, 2018 & 0.909 & 1.354 & 67.18 \\
\hline & Average & 0.510 & 0.902 & 56.54 \\
\hline
\end{tabular}

(Chen et al. 2017), the covering-soil thickness affects root respiration.

In general, the physical and chemical properties of sites A, B, C, and D did not change significantly over the course of a day, and therefore the diurnal changes of root respiration were mainly affected by soil temperature and covering-soil thickness. In addition, the difference in the soil temperature was only about $1{ }^{\circ} \mathrm{C}$ between the four sites in December 2017, but the maximum root respiration was about three times the minimum value. Therefore, the effects of covering-soil thickness on root respiration were greater than the effects of soil temperature in mine reclaimed soil.

\subsection{The contribution of root respiration to total soil respiration}

The $R_{\mathrm{r}} / R_{\mathrm{t}}$ ratio is important for understanding the mechanism of soil respiration and the carbon cycle. The $R_{\mathrm{r}} / R_{\mathrm{t}}$ ratio therefore becomes increasingly important as the area of mine reclaimed soil increases, which will enable us to better understand the influences of reclamation on carbon emissions in mining areas. There were differences in root respiration between the four sites and the rank order of $R_{\mathrm{r}} /$ $R_{\mathrm{t}}$ ratios was $\mathrm{B}>\mathrm{D}>\mathrm{A}>\mathrm{C}$, which was consistent with the rank order of soil respiration. This indicated that the covering-soil thickness affected the root respiration and then affected the $R_{\mathrm{r}} / R_{\mathrm{t}}$ ratio. Although the monthly variations of $R_{\mathrm{r}} / R_{\mathrm{t}}$ ratio were irregular, the $R_{\mathrm{r}} / R_{\mathrm{t}}$ ratio of the entire study area displayed a pronounced monthly variation. When plotted on a monthly basis, the slope of root respiration was lower than that of microbial respiration from November 2017 to December 2017, but the slope of root respiration was higher than that of microbial respiration from December 2017 to April 2018 (Fig. 7). Thus, the $R_{\mathrm{r}} / R_{\mathrm{t}}$ ratio decreased from November 2017 to December 2017 and then increased significantly from December 2017 to April 2018. The microbial respiration was higher than root respiration before January 2018, which suggested that soil respiration was dominated by microbial respiration in the early non-growing season and then by root respiration in the late non-growing season in mine reclaimed soil. Lee et al. (2003) showed that the proportion of overall soil respiration accounted for by root respiration was largely 


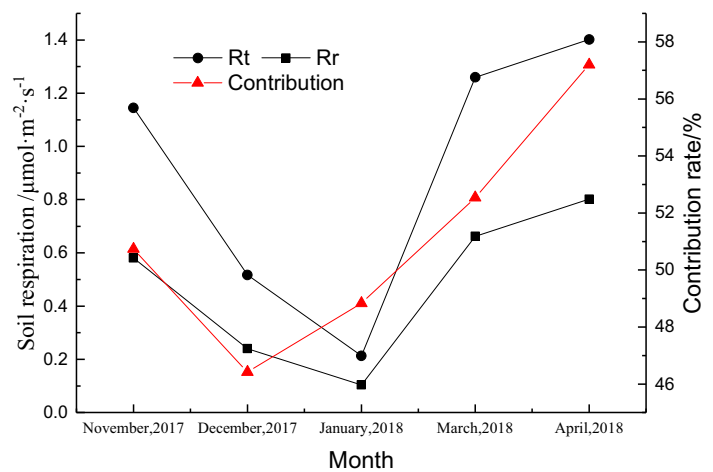

Fig. 7 The contribution of root respiration to total soil respiration at the entire study area in mine reclaimed soil $\left(R_{\mathrm{t}}\right.$ was the total soil respiration and $R_{\mathrm{r}}$ was the root respiration)

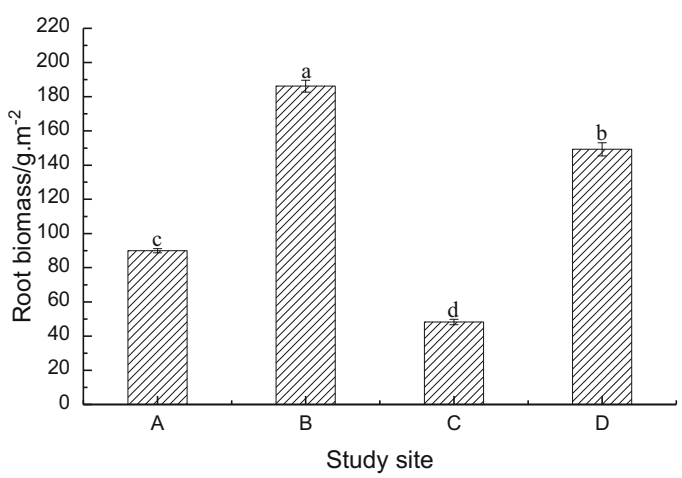

Fig. 8 Average root biomass at study sites with different coveringsoil thicknesses (the covering-soil thicknesses of site A, B, C and D were $10-25,25-45,45-55$ and $55-65 \mathrm{~cm}$, respectively)

between 10 and $90 \%$ in different terrestrial soil types. In our study, the proportion of root respiration to soil respiration was between $16.16 \%$ and $83.02 \%$ (Table 2), which was within a reasonable range. Additionally, the average $R_{\mathrm{r}} / R_{\mathrm{t}}$ ratio was $51.13 \%$ during the non-growing season, indicating the importance of roots as the source of respired carbon in mine reclaimed soil.

\section{Conclusions}

The present study showed that the root respiration exhibited diurnal and monthly variations in mine reclaimed soil. Root respiration had an exponential and positive relationship with soil temperature $(P<0.01)$, but there was no significant correlation $(P>0.05)$ with soil water content. The covering-soil thickness and soil temperature were the main factors that affected root respiration and then affected the $R_{\mathrm{r}} / R_{\mathrm{t}}$ ratios in mine reclaimed soil. The $R_{\mathrm{r}} / R_{\mathrm{t}}$ ratios ranged from $16.16 \%$ to $83.02 \%$, with an average value of $51.13 \%$ during the non-growing season, indicating the importance of roots as the source of respired carbon in mine reclaimed soil.

Acknowledgements This work was financially supported by the National Natural Science Foundation of China (41572333, 51274013). In addition, we express our sincere gratitude to Ada Zhang for polishing the language of this paper.

Open Access This article is licensed under a Creative Commons Attribution 4.0 International License, which permits use, sharing, adaptation, distribution and reproduction in any medium or format, as long as you give appropriate credit to the original author(s) and the source, provide a link to the Creative Commons licence, and indicate if changes were made. The images or other third party material in this article are included in the article's Creative Commons licence, unless indicated otherwise in a credit line to the material. If material is not included in the article's Creative Commons licence and your intended use is not permitted by statutory regulation or exceeds the permitted use, you will need to obtain permission directly from the copyright holder. To view a copy of this licence, visit http://creativecommons. org/licenses/by/4.0/.

\section{References}

Bi YL, Xiao L, Liu RR (2019) Response of arbuscular mycorrhizal fungi and phosphorus solubilizing bacteria to remediation abandoned solid waste of coal mine. Int J Coal Sci Technol 6(4):603-610

Chen XY, Zhou YZ, Yan JP, Wang F, Chen M, Liu BL (2016) Effects of topsoil thickness on active organic carbon distribution in reconstruction soil filled with coal gangue. J China Coal Soc 41(5):1236-1243

Chen M, Chen XY, Gui HR, Liu GJ, Liu BL, Hu ZY (2017) Temperature variation and its response to topsoil thickness from reconstruction soil profile filled with coal gangue. J China Coal Soc 42(12):3270-3279

Chen M, Chen XY, Huang H, Liu BL, Hu ZY (2018a) Effects of fly ash, silty clay loam and loamy sand on the hydraulic conductivity and air permeability of coal gangue. Fresenius Environ Bull 27(4):2035-2042

Chen XY, Zhang LX, Chen M, Xing YZ, Hu ZY, Liu BL (2018b) Aggregate distribution and organic carbon mineralization of reconstructed soils filled with coal gangue in a Huainan coal mining area, china. Fresenius Environ Bull 27(12):8882-8891

Cheng LL, Sun HY, Zhang Y, Zhen SF (2019) Spatial structure optimization of mountainous abandoned mine land reuse based on system dynamics model and CLUE-S model. Int J Coal Sci Technol 6(1):113-126

Chugh YP (2018) Concurrent mining and reclamation for underground coal mining subsidence impacts in China. Int J Coal Sci Technol 5(1):18-35

Dyukarev EA (2017) Partitioning of net ecosystem exchange using chamber measurements data from bare soil and vegetated sites. Agric For Meteorol 239:236-248

Fu Y, Feng F, Fan X, Hu Y, Zhang X (2019) Seasonal dynamics of fine root respiration in the degraded and successional primary Korean pine forests in the Lesser Khingan mountains of Northern China. Ecol Indicat 102:1-9

Hao Q, Jiang C (2014) Contribution of root respiration to soil respiration in a rape (Brassica campestris L.) field in Southwest China. Plant Soil Environ 60(1):8-14 
Hu YC, Li XJ, Fang YD, Liu XR, Zhong WJ (2009) Spatial-temporal variance of reclamation soil physical and chemical character in opencast mine region. J Coal Sci Eng 15(4):399-403

Hu Z, Wang P, Yost RS, Shao F, Duo L (2018) Assessment of several typical physical properties of reclaimed farmland filled with Yellow River sediment in Jining, China. Int J Coal Sci Technol 5(1):36-46

Jørgensen CJ, Struwe S, Elberling B (2012) Temporal trends in $\mathrm{N}_{2} \mathrm{O}$ flux dynamics in a Danish wetland-effects of plant-mediated gas transport of $\mathrm{N}_{2} \mathrm{O}$ and $\mathrm{O}_{2}$ following changes in water level and soil mineral-N availability. Glob Change Biol 18(1):210-222

Lai R, Arca P, Lagomarsino A, Cappai C, Seddaiu G, Demurtas CE, Roggero PP (2017) Manure fertilization increases soil respiration and creates a negative carbon budget in a Mediterranean maize (Zea mays L.)-based cropping system. CATENA 151:202-212

Lee M, Nakane K, Nakatsubo T, Koizumi H (2003b) Seasonal changes in the contribution of root respiration to total soil respiration in a cool-temperate deciduous forest. Plant Soil 255(1):311-318

Li XD, Hua F, Ding G, Li XD, Wan CG (2010) Partitioning soil respiration and assessing the carbon balance in a Setaria italica (L.) Beauv. cropland on the Loess Plateau, Northern China. Soil Biol Biochem 42(2):337-346

Li W, Chen L, Zhou T, Tang Q, Zhang T (2011) Impact of coal gangue on the level of main trace elements in the shallow groundwater of a mine reclamation area. Min Sci Technol (China) 21(5):715-719

Li P, Yang YH, Fang JY (2013) Variations of root and heterotrophic respiration along environmental gradients in China's forests. J Plant Ecol 6(5):358-367

Li YC, Hou CC, Song CC, Guo YD (2016) Seasonal changes in the contribution of root respiration to total soil respiration in a freshwater marsh in Sanjiang Plain, Northeast China. Environ Earth Sci 75(10):848

Li X, Ding G, Zhang C, Niu D, Wan C (2018) Contribution of root respiration to total soil respiration in a semi-arid grassland on the Loess Plateau, China. Sci Total Environ 627:1209-1217

Mu ZJ, Kimura SD, Yo T, Hatano R (2008) Nitrous oxide fluxes from upland soils in central Hokkaido, Japan. J Environ Sci 20(11):1312-1322

Schindlbacher A, Zechmeister-Boltenstern S, Glatzel G, Jandl R (2007) Winter soil respiration from an Austrian mountain forest. Agric For Meteorol 146:205-215

Sokolov D, Androkhanov V, Kulizhskii S, Domozhakova E, Loiko S (2015) Morphogenetic diagnostics of soil formation on tailing dumps of coal quarries in Siberia. Eurasian Soil Sci 48(1):95-105

Thurgood A, Singh B, Jones E, Barbour MM (2014) Temperature sensitivity of soil and root respiration in contrasting soils. Plant \& Soil 382:253-267

Tomotsune M, Yoshitake S, Watanabe S, Koizumi H (2013) Separation of root and heterotrophic respiration within soil respiration; by trenching, root biomass regression, and root excising methods in a;cool-temperate deciduous forest in Japan. Ecol Res 28(2):259-269

Wang W, Peng S, Wang T, Fang J (2009) Winter soil $\mathrm{CO}_{2}$ efflux and its contribution to annual soil respiration in different ecosystems of a forest-steppe ecotone, north China. Soil Biol Biochem 42:451-458

Wang JM, Li XF, Bai ZK, Huang LB (2017a) The effects of coal gangue and fly ash on the hydraulic properties and water content distribution in reconstructed soil profiles of coal-mined land with a high groundwater table. Hydrol Process 31(3):687-697

Wang JM, Wang P, Qin Q, Wang HD (2017b) The effects of land subsidence and rehabilitation on soil hydraulic properties in a mining area in the Loess Plateau of China. CATENA 159:51-59

Xiao W, Hu Z, Fu Y (2014) Zoning of land reclamation in coal mining area and new progresses for the past 10 years. Int J Coal Sci Technol 1(2):177-183

Yan MF, Zhang XS, Zhou GS, Jiang Y (2010) Seasonal dynamics of root respiration in poplar plantations at different developmental stages. Acta Ecol Sin 30(13):3449-3456

Zeng XH, Song YG, Zeng CM, Zhang WJ, He SB (2016) Partitioning soil respiration in two typical forests in semi-arid regions, North China. CATENA 147:536-544

Zhang XH, Li LQ, Pan GX (2007) Topsoil organic carbon mineralization and $\mathrm{CO}_{2}$ evolution of three paddy soils from South China and the temperature dependence. J Environ Sci 19(3):319-326

Zhang C, Nie S, Liang J, Zeng GM, Wu HP, Hua SS, Liu JY, Yuan YJ, Xiao HB, Deng LJ (2016) Effects of heavy metals and soil physicochemical properties on wetland soil microbial biomass and bacterial community structure. Sci Total Environ 557-558:785-790

Zhou BB, Shao MA, Wen MX, Wang QJ, Robert H (2010) Effects of coal gangue content on water movement and solute transport in a China Loess Plateau Soil. Clean: Soil, Air, Water 38(11):1031-1038. https://doi.org/10.1002/clen.201000056 